\title{
Candidate Selection Methods, Cooperation and Legislative Effectiveness
}

\author{
Osnat Akirav ${ }^{1}$ \\ ${ }^{1}$ The Department of Political Science, The Western Galilee College, Akko, Israel \\ Correspondence: Osnat Akirav, The Department of Political Science, The Western Galilee College, Akko, Israel. \\ E-mail: osnatak@bezeqint.net
}

Received: December 7, 2017 Accepted: December 26, 2017 Online Published: January 22, 2018

doi:10.5539/res.v10n1p46

URL: https://doi.org/10.5539/res.v10n1p46

\section{Abstract}

This study investigates whether differences in candidate selection methods and/or the changes in the Israeli political system affect cooperation between parliament members and whether such cooperation explains legislative effectiveness. To examine these issues, we discuss different types of cooperative strategies using a scale we devised that defines three options for cooperation: 1) uncooperative, 2) cooperation within the party and 3) cooperation between parties. Then, we categorize the various methods that Israeli political parties have used to select their candidates since the establishment of the state, creating four categories of a variable we call the effect of the primaries. Additionally, we consider differences in four periods of changes in the Israeli party system. Finally, we assess the results of cooperation in light of our dependent variable, legislative effectiveness, using data from 1949 to 2015. Our findings indicate that the majority of bills passed without cooperation, but when cooperative strategies were used, they usually involved inter-party rather than intra-party support. Furthermore, the adoption of primaries reduced the probability of passing bills. In addition, when one party was dominant, $68 \%$ of the representatives initiated legislation alone, while during the multi-polar fragmented period $41.9 \%$ cooperated with legislators from other parties.

Keywords: the effect of the primaries, cooperation scale, legislative effectiveness, Israeli party system

\section{Introduction}

Legislators in modern democracies tend to cooperate with each other when they have common goals (Fenno 1973; Mayhew 1974). However, we pose several questions about cooperation in the Israeli political system. First, what form does this cooperation take? Does it exist intra-party and/or between parties? Is it personal or more general? Second, do different candidate selection methods affect cooperative strategies? Third, do differences in the Israeli party system affect cooperative strategies? Fourth, does such cooperation increase the probability of passing bills, which we define as the measure of legislative effectiveness?

To answer these questions, we first discuss different types of cooperative strategies (the independent variable of the study) using a scale we devised that defines three options for cooperation: 1) uncooperative (solo player), 2) cooperation within the party and 3) cooperation between parties. Second, we detail the rationale behind these strategies. Then, we present the differences in candidate selection methods and describe the independent variable we created called the effect of the primaries. We also classify the differences in the Israeli party system into four categories. Finally, we assess the results of cooperation in light of our dependent variable, legislative effectiveness, measured using data from 1949 to 2015, covering the first term of the Israeli parliament (the Knesset) through the 19th Knesset. Thus, the paper contributes to the literature by improving our understanding about whether cooperative strategies, the effect of the primaries and differences in the party system increase the probability of passing bills, meaning, raising the level of legislative effectiveness.

\subsection{Cooperative Strategies}

Cooperative strategies, although not a new phenomenon, are becoming important in many research fields such as economics, management, education and politics. However, there is no theory of cooperation acceptable to scholars from the various fields (Nowak 2006; Carter, Clegg, \& Kornberger 2008). While an exploration of the broader theoretical questions involving cooperation is beyond the scope of this paper, we will focus on two patterns of political cooperation that constitute our independent variable: cooperation between political parties within parliament and intra-party cooperation.

Theories such as game theory or strategic management theory provide some partial descriptions of cooperative strategies. The existing studies on the topic focus on the sources, benefits and implications of cooperation, as well as methods for achieving it (e.g., Faulkner 1995; Lau 2004; Child, Faulkner, \& Tallman. 2005). In the political field, scholars have 
examined inter-parliamentary cooperation, cooperation within parliament and intra-party cooperation (Porter, Much, Newman, \& Warmbrand 2005; Crum \& Fossum 2009). They suggested that the incentives to cooperate within parliament could be the representatives' constituency, their desire to be re-elected or their social networking. Hence, we can say that the decision to cooperate with others is based mainly on the desire to achieve goals framed previously.

Schlesinger (1966) was the first to claim that representatives are multi-dimensional actors, unlike later scholars who argued that the goal of most representatives is to be re-elected (Mayhew 1974). Schlesinger's successors maintained that the multiple objectives representatives have might often conflict with one another (Fenno 1978). Others contended that these objectives lead them to adopt behavioral strategies based on the procedures of their parliaments (Strøm 1997).

However, in order to accomplish their objectives representatives need to distinguish themselves from their colleagues (Carey \& Shugart 1995). Hence, we might expect representatives to be uncooperative with each other. Indeed, Lou (2004) described them as solo players. Nevertheless, studies show that representatives do use various cooperative strategies depending on the interests they want to advance (Soroka, Penner,\& Blidook 2009; Tam-Cho \& Fowler 2010). As mentioned previously, that cooperation can occur at the inter-parliamentary, between parties and intra-party levels.

Most studies on inter-parliamentary cooperation have investigated the EU, and posited that the goal was strengthening national parliamentary power in Europe through inter-parliamentary cooperation by creating networks with other parliaments. Inter-parliamentary cooperation enables parliaments to increase their control over their governments (Kiiver 2006; Crum \& Fossum 2009). For example, Crum and Fossum (2009) maintained that EU inter-parliamentary relations resemble a parliamentary network, which is useful for describing how previously independent bodies have become linked in a horizontal structure with functional relations between them. However, the flexibility of the parliamentary network limits its analytical utility.

Cooperation within parliament can be based on several incentives, the first of which is the representatives' constituency. If cooperation promotes the representatives' interests in the eyes of their constituency, they will do so (Soroka et al. 2009; Marangoni \& Tronconi 2011). For example, Marangoni and Tronconi (2011) found that legislators with strong territorial roots behave as agents of the local community, promoting its interests and demands in their parliamentary activity. The second incentive is re-election. When cooperation enhances legislators' re-election possibilities, they will do so. Bowler (2010) determined that the number of private bills initiated by MPs was both influenced by the electoral margin from the previous election and positively associated with electoral performance in the subsequent election. The third incentive is social networking. When the potential partners are part of their social network, representatives will cooperate with them (Porter et al. 2005; Tam-Cho \& Fowler 2010). Congress is an example of a social network, a social entity in which the actors are interdependent and have relationships with others in the network.

Intra-party cooperation can be based on party unity or being part of the majority party. When cooperation is a demand of party unity or the majority party (Cox \& McCubbins 2005; Martin \& Vanberg 2008; Crisp \& Driscoll 2012), representatives will comply with the demand. Cox and McCubbins (2005) claimed that the "cartelization" of the majority party makes strategic use of cameral procedures and the distribution of resources to ensure that those bills that reach a vote for final passage will not divide the government coalition and will preserve the image of the ruling party for the good of its members. Crisp and Driscoll (2012) examined the strategic choice of voting procedures and their relationship to maintaining party unity. Representatives choose their strategies based on the reasoning that some items have different value than others. Finally, Martin and Vanberg (2008: 514) claimed that the logic of the coalition's behavior appears to change gradually over the life of the government from one of cooperation and compromise to one of electioneering and position taking.

In addition to these three areas of cooperation, there is one more incentive to cooperate--personal attitudes. When cooperation is part of the representatives' personal attitudes (Crisp et al. 2004), they will do so. For example, Crisp et al. (2004) found that the bills initiated by individual representatives reflected their personal vote-seeking incentives in terms of their focus on national versus local goals.

We posit that representatives will first work individually. However, if they decide to cooperate, they will do so with other representatives across affiliations when they believe that doing so will help them realize their goal of being re-selected to run, being re-elected, or achieving higher office. They will cooperate with their party colleagues only when they will feel that the cooperation does not threaten their ability to be re-selected to run again. There is a "balance of terror" between the representatives' desire to be re-selected and re-elected and their desire to advance specific agenda. Previous studies have established that most bills are not controversial, and representatives from different parties can agree on the issues suggested by other representatives from other parties (Maor 2009). Thus, when representatives within a party share attitude on a given topic, the likelihood of cooperation within the party is greater. However, when representatives within the party have conflicting attitudes, they are less likely to cooperate and may seek the support of those in other parties. 
Based on these theories we expect that:

H1: Members of the Knesset (MKs) will use a ladder of cooperative strategies. First, they will prefer working alone. If they are unsuccessful in accomplishing their goals, they will then cooperate with colleagues from other parties. If they cannot find consensus there, they will cooperate with colleagues from their own party.

The decision to cooperate is a function of several factors, one of which is the method by which the MK is selected for the party's list. The competition between MKs for a place on the party's list is much more intensive when the elected body is large. MKs must reach many more voters in order to be re-selected.

\subsection{Candidate Selection Methods: the Effect of the Primaries}

In a democracy, electoral competition occurs between parties and within parties. Shomer (2014) claimed that the vast literature on the relationship between electoral systems and candidate selection processes fails to provide systematic empirical evidence for the existence or lack of this relationship. In her study she showed that territorial organization and regional patterns are among the chief factors accounting for variations in selection processes across parties. Parties competing in unitary systems will tend to adopt more centralized and exclusive selection processes, whereas parties in federal countries will adopt more inclusive and decentralized selection mechanisms.

This study will concentrate first on the competition within parties and then examine the changes in the party system that have occurred in Israel since its establishment. However, it is important to note that different electoral systems such as majority rule, proportional representation and plurality voting create different incentives for parties and individual representatives before the elections and between the elections. We will address this point later in the paper when we discuss the Israeli context and the composition of the variable of the political system.

One of the areas of competition within parties is candidate selection methods, which have been the focus of study in the last two decades (Rahat \& Hazan 2001; Sandri, Seddone, \& Venturino, 2015; Cross et al. 2016). Parties adopt a specific method for choosing candidates for a variety of reasons: 1) it is required by law, 2) they want to increase their votes, 3) it is part of the party's ideology and 4) the size of the party (Hazan \& Rahat 2010; Put et al. 2016).

Hazan and Rahat (2010) developed a framework for comparing these selection procedures. Their model has four dimensions of candidate selection: candidacy, party selectorate, decentralization, and voting/appointment systems. In the current study we will concentrate on the selectorate dimension. Rahat and Hazan (2001) propose a selectorate continuum ranging from only one person to the entire electorate. Thus, their continuum ranges from the most exclusive selectorates to the most inclusive ones. In between both extremes, various bodies might have the task of choosing the party leader: the party elite, a parliamentary party group, a selected party agency, or party members. Rahat and Hazan's (2001) continuum details how many people are involved in the selectorate. While this fact is important, we argue that it creates an effect that we call the effect of the primaries.

When a party adopts primaries as its method of selecting candidates, other parties are forced to debate whether they should adopt primaries as well. For example, previous studies showed that the adoption of primaries by the Labor Party in Israel and afterwards by other parties produced several changes. First, it transformed the Knesset into an independent body and, hence, provided a functioning system of checks and balances between the legislature and the executive. Second, it shifted power from the Jewish religious minority to the secular majority and even contributed to the increase in the relative power of the Arab parties (Barak-Erez 2002; Benvenisti 2002). Third, it changed the dynamic in parliamentary work even within parties that did not have primaries (Hazan and Rahat 2006; Akirav 2010; Cross, Kenig, Pruysers, \& Rahat, 2016).

\subsection{Legislative Effectiveness}

Legislation is considered one of the most important roles of legislators, so it has received most of the research attention in the field (Wawro 2000; Cox \& McCubbins 2005; Akirav 2014). Matthews (1960) was the first scholar to create an index of legislative effectiveness by measuring the ability of representatives to pass bills., which is the definition we use as well. Most subsequent studies adopted this approach (Howell, Alder, Cameron, \& Riemann, 2000; Wawro 2000; Garand \& Burke 2006). Other scholars replaced legislative effectiveness with legislative productivity. They suggested additional ways to measure legislative productivity such as the numbers of bills representatives sponsored (Wawro 2000; Garand \& Burke 2006) and the proportion of bills that the legislators sponsored that passed (Matthews 1960).

In contrast, recent studies emphasize the idea that the process is as important as achieving the goal (Cox \& Terry 2008; Akirav 2014; Volden \& Wiseman 2014). Cox and Terry (2008) suggested combining two measurements, counting the number of bills from each legislator that come out of committee and the number that are passed in a given Congress. Another group of researchers focused on the performance of legislators using subjective measures or a mix of subjective and objective measures (Miquel \& Snyder 2006; Akirav 2014). Miquel and Snyder (2006) examined legislative effectiveness with data collected by the North Carolina Center for Public Policy Research. They asked legislators, 
lobbyists and journalists to assess how effective each legislator was during a specific session. However, as Howell et al. (2000) suggested, more attention must be paid to the theoretical foundations of legislative productivity. Based on their suggestion, Akirav (2014) developed a new scale, reflecting a new way of looking at productivity. The scale includes various parameters such as private bills, parliamentary questions, motions for the agenda and one-minute speeches, which have never been explored together. Volden and Wiseman (2014) developed a legislative effectiveness score (LES) based on fifteen indicators that collectively capture the proven ability of a representative to advance his/her agenda through the legislative process into law.

The research assumes that legislators are rational actors, meaning that they assess the benefits and disadvantages of engaging in a particular behavior, resulting in choices whose consequences affect significant numbers of people. In other words, to act rationally means to choose better alternatives over worse ones (Brams 2014). Scholars have also maintained that being rational means being strategic (e.g., Riker 1996; Powell, Lovallo, \& Fox, 2011). Legislators will choose to cooperate with their colleagues when they will think that it will help them accomplish the goals they seek for their voters and for themselves. Furthermore, when the subject of the legislation is important to legislators, they will cooperate across party lines and regardless of affiliations such as party, gender, being a minority, and membership in the coalition or opposition. It is important to note that the passage of a single piece of legislation is a difficult task that demands a great deal of attention and work. Hence, we assume that legislators prefer to cooperate when they think that by doing so they will increase the likelihood of the bill's passing.

In this paper we counted only the initiators of a given bill and did not take into account co-sponsorship, which can be considered one method of cooperation. It is important to note that the sponsorship of bills has become a very important part of the legislative process and exists in legislatures worldwide. It is unique because sponsorship is not about voting on legislation. Members of Congress invest a great deal of time convincing their colleagues to sponsor their legislation (Koger, 2003; Fowler 2006). Even though sponsoring bills has no formal effect on the legislative process, the sponsorship enables legislators to take a position (Koger, 2003; Rocca \& Gordon, 2010) and can have policy implications (e.g., Kessler \& Krehbiel, 1996; Koger, 2003). The sponsorship of bills gives political leaders low cost information about the political gain they can achieve from legislation (Koger, 2003). Alternatively, legislators can use the list of a bill's co-sponsors to assess its level of support, ideological stance and endorsement by reputable colleagues (Wilson \& Young, 1997).

For the purposes of this paper, we might think of cooperation as the extent to which representatives work together and vote together to pass legislation. If this definition is correct, it is obvious that, all else being equal, more cooperation leads to more legislative productivity. However, an additional variable needs to be considered - the effect of the primaries. Representatives do not operate in a vacuum. They compete with their party colleagues during the selection process and then they compete with their colleagues from other parties during the election process. Therefore, they must distinguish themselves from any other candidates while they are attempting to pass bills.

Based on these discussions of cooperative strategies, candidate selection methods and legislative effectiveness, we predict that:

H2: MKs who work alone will be more legislatively effective than MKs who cooperate with others. However, MKs who cooperate between parties will be more legislatively effective than those who cooperate with their colleagues from the same party.

H3: During the primary-less period, legislative effectiveness will be the highest compared to the other periods. The introductory period will have more legislative effectiveness compared to the intermediate and maturation periods. Finally, the intermediate period will correspond with the lowest level of legislative effectiveness.

\section{The Israeli Context}

While focusing on the Israeli case may seem rather parochial, we maintain that its experience has the potential to contribute to both a comparative and theoretical analysis. Israel has a unicameral parliament whose members are elected by a closed-list system of proportional representation with the entire country serving as one constituency (120 MKs). Its political system has been described as a hybrid, combining electoral rules, a fragmented party system and bipolar competition (Rahat \& Hazan 2005). Israel has no formal constitution, but over time the Knesset has enacted 12 Basic Laws that are the building blocks of a constitution-in-the-making.

Israel can be considered a microcosm of political changes. In the first 30 years of its history, Israeli politics was dominated by the Mapai Party (later the Labor Party), which, although it never won an outright majority, always formed the basis of the government. After Labor's defeat in 1977, and especially during the 1980s, the Israeli party system fragmented, and chronic policy stalemates developed. Since the 1990s, its political system has shifted into a multipolar system, where power is much more diffused among the parties. 
Two successive reforms sought to remedy the problems the Israeli political system faced. The first, passed in 1992 and applied in 1996, introduced the direct election of the prime minister. In this reform the formal requirement for an investiture vote was removed, and a successful no-confidence vote needed an absolute majority of MKs. Seats were allocated in a proportional way, just as before the direct election of the prime minister. This change affected the size of the parties; the big parties shrank while some of the small parties became oversized. The change also affected the number of parties within the government and the share of seats of each party in the government. As a result, the formateur party and the other parties were almost the same size. Furthermore, the 15th Knesset opened with Ehud Barak as prime minister (June 1999), but in February 2001 a special election for prime minister took place and Ariel Sharon was elected. The share of seats remained the same during the 15th Knesset, thereby creating a very fragmented parliament that had difficulty passing legislation. The second reform required that parties earn $1.5 \%$ of the vote to receive a seat in parliament, which reduced the number of parties in the Israeli legislature.

The election of 1977 was a milestone in the selectorate, because two parties decided to expand the selectorate body from a nominating committee to party delegates and party members.

The third reform was adopted only by the Labor Party, which in 1992 decided to hold closed primary elections consisting of registered party members who had paid membership fees to choose its candidates. The Labor Party won 44 seats in the 1992 election, and other parties thought that democratization in the candidate selection process would give them more seats in future elections. Therefore, during the 13th Knesset (1992-1996), parties began to consider the possibility of adopting similar methods for choosing their candidates. Consequently, the candidate selection method soon became a major item on the public agenda.

Before the elections for the 14th Knesset took place, three more major parties decided to use primaries to determine their list of candidates: Likud, Meretz and Tzomet.

During the 14th Knesset, the debate regarding primary elections continued to be on the parties' agenda, but now the voices were different. MKs, journalists and academic researchers began to emphasize the consequences of the primaries. Hence, prior to the general election of 1999 , three of the four parties that had adopted primaries returned to their previous candidate selection method (a nominating committee or party delegates). Since 1999, the Labor Party has been the only party that still uses primaries as a candidate selection method, despite loud calls from within, as well as from the other three parties, to abandon them. However, beginning with the election for the 18th Knesset the Likud Party adopted the use of primaries again, and for the 19th Knesset the Habayit Hayehudi party used primaries as the candidate selection method for the first time.

In the 14th Knesset $62.5 \%$ of the MKs were selected by primaries (the highest number ever). Then, in the 15th -17 th Knesset terms, there was a significant decrease in the number of MKs chosen by primaries, and the preferred candidate selection method became the selection by the party's delegates. In the most recent Knesset terms more MKs were selected by primaries (39\% and $51 \%$, respectively) and there was an increase in the number of MKs selected by nominating committees (46\% and $33 \%$, respectively).

Based on the data presented we created a variable called the effect of the primaries, which has four categories: 1) the primary-less period in which none of the parties used party members as the selectorate body (1st-12th Knesset terms) (coded ' 1 '); 2) the introductory period, the first significant time that parties used party members as the selectorate body. The period is characterized by enthusiasm and curiosity about the adoption of primaries as an innovative selection method among the parties that adopted it and other parties looked on as outsiders (13th-14th Knesset terms) (coded '2'); 3) the intermediate period in which most of the parties that adopted primaries stopped using them (15th-17th Knesset terms) (coded ' 3 ') and 4) the maturation period in which some parties re-adopted using primaries, whereas others went back to selecting candidates through nominating committees (18th-19th Knesset terms) (coded '4').

After the failure of the two reforms mentioned previously to address the problems they were intended to fix, in 2001 (applied in 2003) the parliament restored most of the old electoral system, with one important additions: a semi-constructive no-confidence vote (to remove a sitting prime minister, at least $61 \mathrm{MKs}$ must vote for a specific alternative candidate). In 2004 and 2014 the threshold for receiving a seat in parliament was raised to $2 \%$ and $3.25 \%$ respectively. The changes in the threshold affected the opportunity of various parties to form a government.

What impact have these changes had on legislation? As Appendix 1 demonstrates, in the 1st -11th Knessets, government-initiated legislation accounted for $80 \%-90 \%$ of the bills passed, but since the 13th Knesset this percentage has declined to $40 \%-50 \%$.

Table 1 provides a look at other democracies in a comparative manner. It demonstrates that the percentage of bills passed in Israel during 1999-2009 or 2009-2013 is similar only to the UK (with higher numbers both in proposing bills and passing them). In other countries the passage rate is much higher even though the absolute number of bills proposed in 
Israel is much higher from a smaller number of MKs (Israel has 120 representatives, while the Netherland has 150 , Austria has 186, and Ireland has 166).

Table 1. The extent of private legislation in parliaments

\begin{tabular}{|c|c|c|c|c|c|}
\hline Country & $\begin{array}{c}\text { Data } \\
\text { collection } \\
\text { period }\end{array}$ & Number & Number of & Number of & Percentage of \\
private bills & private & private bills \\
proposed & pills & passed & \\
\hline Israel & $1949-1999$ & 120 & 9699 & 913 & $9.4 \%$ \\
\hline Israel & $1999-2009$ & 120 & 13003 & 653 & $5.02 \%$ \\
\hline Israel & $2009-2013$ & 120 & 7577 & 384 & 5.06 \\
\hline Austria & $1999-2008$ & 183 & 782 & 248 & $32 \%$ \\
\hline Ireland & $2000-2010$ & 166 & 187 & 2 & $1 \%$ \\
\hline UK & $2000-2010$ & 650 & 915 & 48 & $5 \%$ \\
\hline Netherlands & $2000-2010$ & 150 & 118 & 25 & $21 \%$ \\
\hline
\end{tabular}

The changes in candidate selection methods increased the amount of legislation proposed, but not the percentage of bills that passed. One explanation for this outcome may be that the passage of private bills and the drop in the passage of government bills are a result of the changes in the party system that happened simultaneously with the adoption of primaries.

\section{Methodology}

In order to test the research hypotheses, we gathered all of the private bills passed from the first Knesset through the 19th Knesset (1949-2015). During this period, 1,951 private bills out of 30,292 that were proposed were passed. We then looked at each bill with regard to its initiators only (we did not count MKs who co-sponsored a given bill that passed) to see what kind of cooperative strategy resulted in its passing. We coded those bills involving only a single representative as ' 0 ', those that required intra-party cooperation as ' 1 ' and those that included cooperation between parties as ' 2 '. The last group included cooperation between various options such as minority member parties, coalition versus opposition parties, ultra-religious and secular parties. We did not categorize each option as a different kind of cooperation, because we wanted to create sharp, distinct differentiations in the variable, cooperative strategies. When an MK decides to cooperate with at least one other MK from another party, they are willing to move outside their comfort zone.

We deal with multiple MKs cooperating in the same was as just two MKs cooperating. When their names are added to a bill, they are defined as its initiators. (We excluded co-sponsoring). Since 2003, if the cost of implementing the bill is high (more than 5 million NIS), the Knesset requires more than 50 MKs to support the bill in each of its three readings. One can argue that the requirement might be an incentive for multiple initiators. However, we did not consider the cost of implementing the bill, because doing so would require a content analysis of each bill, which we did not do.

We are aware that our decision to create a trichotomous variable, particularly one in which the third category does not distinguish among several options, might limit the explanations of the cooperative strategies and legislative effectiveness. However, we wanted to concentrate on individual actions, cooperation within a party and cooperation between parties.

Figure 1 illustrates the trends in cooperative strategies during the various Knesset terms. The most frequent option is 
working alone (with the exception of the 10th, 18th and 19th terms). Next is cooperation between parties (including coalition versus opposition, minority, ultra-religious and secular parties).

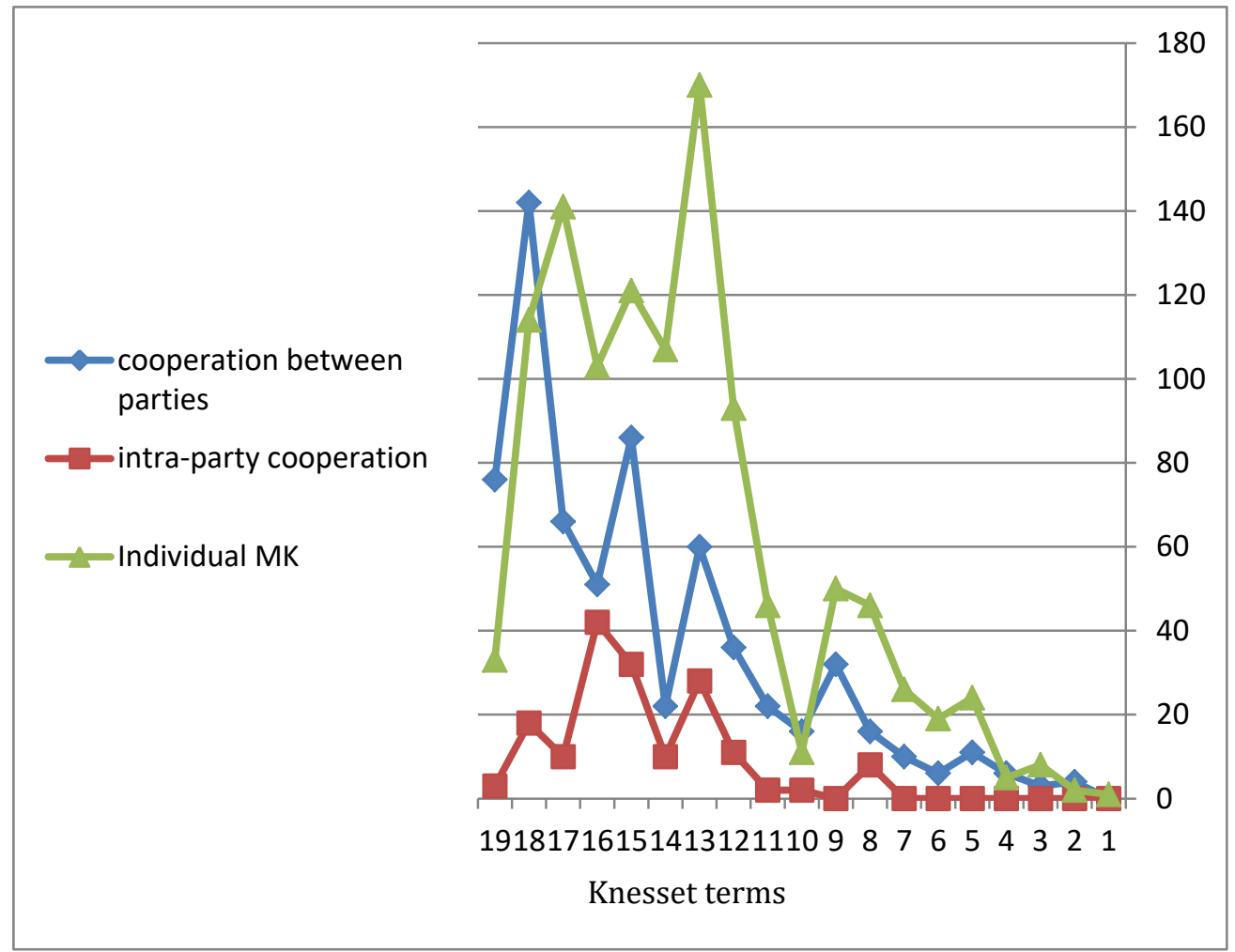

Figure 1. The trends in cooperative strategies during the various Knesset terms

In order to analyze the influence of the changes that occurred in the Israeli party system since its establishment (as described earlier), we created a variable called party system. The variable has four categories. From the first Knesset term until and including the 7th Knesset term when the Mapai Party (later the Labor Party) dominated Israeli politics, we called the one party dominant period (coded '1'). From the 8th Knesset until and including the 13th Knesset the Israeli party system fragmented and had two blocs, so we called this period the bi-polar system (coded '2'). From the 14th Knesset until and including the 15th Knesset Israelis voted directly for the Prime Minister, which reduced the size of the large parties and increased the size of the smaller parties. We called this period the

disintegration of the big parties (coded ' 3 '). Finally, from the 16th Knesset until the present the Israeli party system shifted into a multi-polar system that we called the multi-polar fragmented period (coded '4').

Finally, we determined the length of each Knesset term in months, which is listed in Table 1. We did so for two reasons. First, even though by law the Knesset term is four years, there is an option to pass a bill that would shorten the length of the Knesset term and call for new elections. Second, given that passing bills is a long process, the length of the Knesset term might affect its legislative effectiveness. Therefore, we would expect shorter Knesset terms to be less successful than ones that run their full length.

\section{Findings and Discussion}

From the beginning of the 1st Knesset in 1949 until the end of the 19th Knesset in March 2015, Israeli MKs initiated 30,292 private bills, but just 1,951 became law (6.44\% of the total). Figure 2 illustrates the percentage of the bills that passed compared to government bills. 


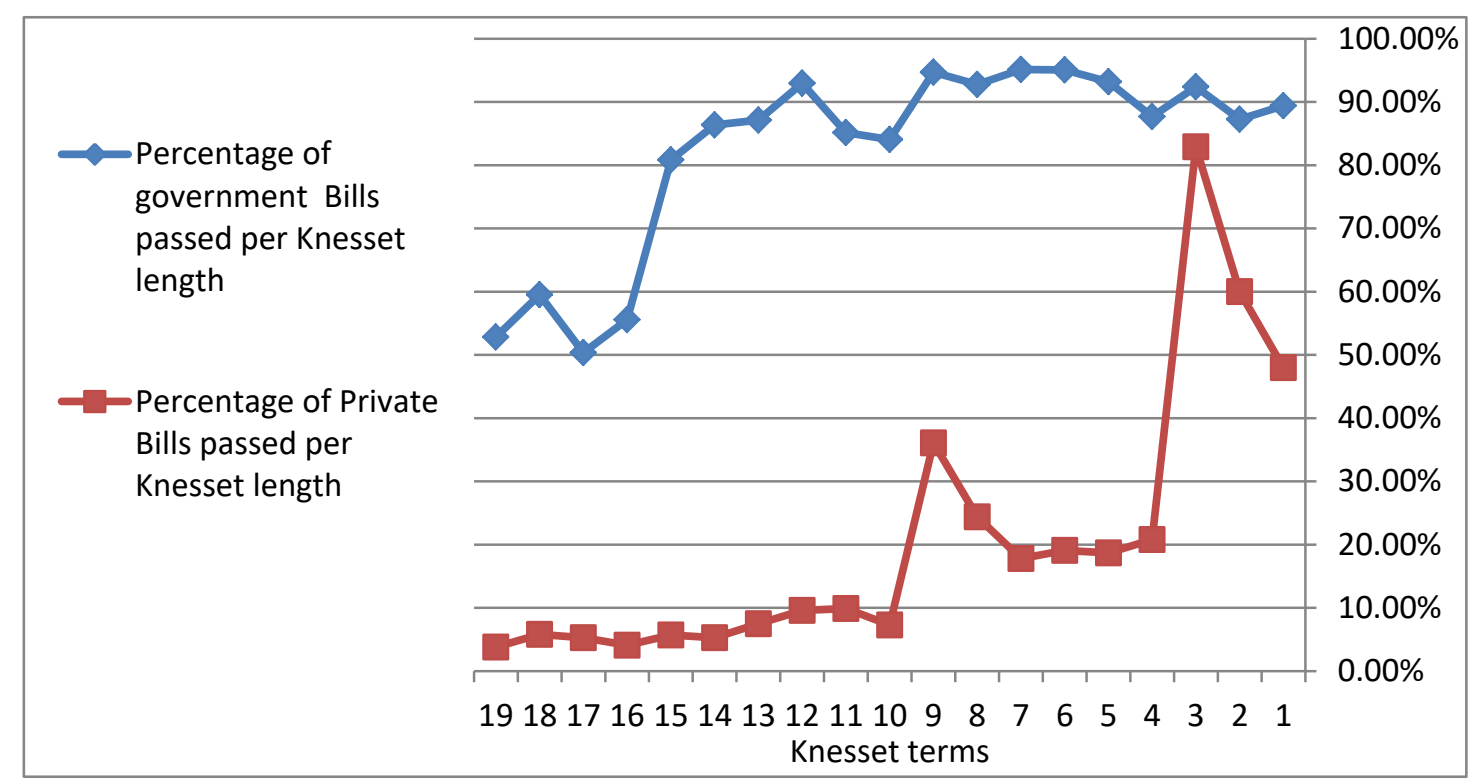

Figure 2. The percentage of the bills that passed compared to government bills by Knesset term.

Here we can see an increase in the number of the bills initiated compared to previous Knesset terms, but a decrease in the number of bills that passed. Some might say that such numbers indicate a high degree of productivity on the part of the representatives, while other would argue that the actual measurement that matters is the number of bills that passed (Wawro 2000; Cox \& Terry 2008).

Strategic alliances - How do they work?5.1

As described previously, the variable cooperative strategies is a trichotomous one. We coded those bills involving only a single representative as ' 0 ', those that required intra-party cooperation as ' 1 ' and those that included cooperation between parties as ' 2 '.

Our first research hypothesis posited that MKs would prefer to work alone, followed by cooperating with colleagues across parties and finally, with colleagues from their own party. The data show that throughout the history of the Knesset 1,120 (57.4\%) bills did not involve any cooperation between MKs at all, meaning they acted alone. This behavior is rational and strategic, because legislators choose the best alternative as they see it (Powell et al. 2011; Brams 2014) and behave in accordance with their personal attitudes (Crisp et al. 2004). It also means that even though legislators share the same party, they do not necessary share common goals that would motivate them to cooperate with each other (Matthews 1960; Mayhew 1974).

Acting alone means there is no risk of being betrayed, but there is a zero-sum outcome. Rational choice theory suggests that individuals, as rational actors, trust others only if the potential gains are greater than the potential losses (Axelrod 1984; Chaudburi, Sopher, \& Strand, 2002).

In addition, the data indicate that MKs tended to cooperate with each other in order to pass 831 bills. This cooperation took two forms. Of the bills, 166 (8.5\%) involved intra-party cooperation and $665(34.1 \%)$ required cooperation between parties. As Nowak (2006) claimed, cooperation means that people forgo some of their selfishness to help one another.

Based on the results, we can see that the preferred cooperation strategy is between parties rather than intra-party. The results strengthen previous studies regarding the use of sponsorship as a way to cooperate with colleagues during the legislative process (e.g., Campbell 1982; Koger 2003; Rocca \& Sanchez 2008). The cooperative strategies model posits three situations under which legislators will cooperate: to meet the demands of their constituency, to advance the goal of being re-elected or in response to social networking (Kiiver 2006; Tam-Cho \& Fowler 2010). Hence, we can say that the decision to cooperate with others is based mainly on the desire to achieve the goals framed previously.

The data also demonstrate that initially MKs do not cooperate with each other and prefer to work alone. As indicated before, legislators need to distinguish themselves from their colleagues, mainly their party colleagues (Carey \& Shugart 1995) in order to be re-selected and re-elected. Furthermore, when they do cooperate, they do so first with members from other parties and only as a last resort with those from their own party. This finding accords with previous studies demonstrating that intra-party cooperation is influenced by representatives' perceptions about different values for 
different issues and the internal distribution of power within the party (Pedersen 2010; Crisp \& Driscoll 2012). However, in daily parliamentary life representatives do use various cooperative strategies depending on the interests they want to advance (Tam-Cho \& Fowler 2010; Marangoni \& Tronconi 2011).

\subsection{Cooperative Alliances - Do They Pay Off?}

The second hypothesis maintained that MKs who work alone are more legislatively effective than those who cooperate with others. However, those who cooperate between parties will be more effective legislatively than those who cooperate with their colleagues from the same party. To test this hypothesis, we conducted several statistical analyses. First, we conducted an ANOVA and a post-hoc Tukey test to determine whether different cooperative strategies caused differences in legislative effectiveness.

As Table 2 shows, the differences between cooperative strategies are significant. Those who decided to cooperate were more successful if they chose to do so between parties rather than intra-party. Analyzing the names of the MKs who cooperated between parties shows us that most of them sought support from parties outside their position in the government. Thus, coalition members went to opposition parties seeking cooperation as opposed to the parties that were also part of the coalition.

Table 2. The differences between cooperative strategies and legislative effectiveness

\begin{tabular}{|l|r|r|r|c|c|}
\hline & Sum of Squares & Df & Mean Square & F & Sig. \\
\hline Between Groups & 1429.578 & 2 & 714.789 & 7.687 & .000 \\
Within Groups & 181137.351 & 1948 & 92.986 & & \\
Total & 182566.929 & 1950 & & & \\
\hline
\end{tabular}

\begin{tabular}{|l|l|r|r|r|}
\hline (I) Cooperative strategy & (J) Cooperative strategy & Mean Difference (I-J) & Std. Error & Sig. \\
0 & 1 & $3.0849 \%^{*}$ & $0.8020 \%$ & .000 \\
& 2 & $0.7482 \%$ & $0.4721 \%$ & .252 \\
1 & 0 & $-3.0849 \%$ & $0.8020 \%$ & .000 \\
2 & 2 & $-2.3367 \%$ & $0.8367 \%$ & .015 \\
& 0 & $-0.7482 \%$ & $0.4721 \%$ & .252 \\
& 1 & $2.3367 \%$ & $0.8367 \%$ & .015 \\
\hline
\end{tabular}

Second, we conducted a stepwise regression with legislative effectiveness as the dependent variable and the independent variables of cooperative strategies and the length of the Knesset terms. Table 3 presents the findings. 
Table 3. Cooperative strategies, the length of the Knesset term and legislative effectiveness

Coefficients $^{\text {a }}$

\begin{tabular}{|c|c|c|c|c|c|}
\hline \multirow[t]{2}{*}{ Model } & \multicolumn{2}{|c|}{$\begin{array}{c}\text { Unstandardized } \\
\text { Coefficients }\end{array}$} & $\begin{array}{l}\text { Standardized } \\
\text { Coefficients }\end{array}$ & $\mathrm{t}$ & Sig. \\
\hline & B & Std. Error & Beta & & \\
\hline (Constant) & 36.310 & .593 & & 61.229 & .000 \\
\hline $\begin{array}{l}\text { Cooperative } \\
\text { strategy }\end{array}$ & .620 & .162 & .059 & 3.816 & .000 \\
\hline Knesset length & .087 & .031 & .058 & 2.800 & .005 \\
\hline
\end{tabular}

a. Dependent variable: Legislative effectiveness

Using these different statistical procedures, our findings indicate that cooperating with colleagues from other parties increases the probability of passing bills. In addition, the longer the Knesset term, the more likely the passage of legislation. This model explains $53.7 \%$ of the variance in legislative effectiveness. Therefore, we can conclude that, if MKs decide to cooperate, it is better for them to cooperate with MKs from other parties in order to pass legislation. Nevertheless, MKs acting alone can also be successful in passing bills. Thus, MKs who want to pass legislation should choose between acting alone or seeking inter-party cooperation.

\subsection{The Effect of the Primaries and Legislative Effectiveness}

The effect of the primaries is a new variable we developed (in our case, an independent one) that has four categories: 1) the primary-less period (1st-12th Knesset terms), 2) the introductory period (13th-14th Knesset terms), 3) the intermediate period (15th-17th Knesset terms) and 4) the maturation period (18th-19th Knesset terms).

We first wanted to investigate whether there is a connection between the two independent variables, cooperative strategies and the effect of the primaries. We ran a $\times 2$ test and found that there is a significant connection $\left({ }^{2} 2=151.006, \mathrm{sig}=0.000\right)$. In the primary-less period more MKs initiated bills without cooperating with others. In contrast, during the maturation period, most MKs cooperated between parties.

H3 expected that during the primary-less period legislative effectiveness would be the highest compared to the other periods. The introductory period would have more legislative effectiveness compared to the intermediate and maturation periods. Finally, the intermediate period would correspond with the lowest level of legislative effectiveness. To test the hypothesis, we conducted an ANOVA and a post-hoc Tukey test to determine whether the effect of the primaries influenced legislative effectiveness. As Table 4 shows, the differences between the effects of the primaries are significant $(\mathrm{F}=483.701, \mathrm{Sig}=0.000)$. During the primary-less period legislative effectiveness was the highest compared to the other periods. The introductory period saw more legislative effectiveness compared to the intermediate and maturation periods. Finally, the intermediate period corresponded with the lowest level of legislative effectiveness. 
Table 4. The effect of the primaries and legislative effectiveness

Legislative effectiveness

\begin{tabular}{|l|r|r|r|r|r|}
\hline & Sum of Squares & \multicolumn{1}{|c|}{ Df } & Mean Square & F & Sig. \\
\hline Between Groups & 77962.175 & 3 & 25987.392 & 483.701 & .000 \\
Within Groups & 104604.754 & 1947 & 53.726 & & \\
Total & 182566.929 & 1950 & & & \\
\hline
\end{tabular}

\begin{tabular}{|c|c|c|c|c|}
\hline \multicolumn{2}{|c|}{$\begin{array}{l}\text { (I) The effect } \\
\text { of the (J) The effect of } \\
\text { primaries the primaries }\end{array}$} & Mean Difference (I-J) & Std. Error & Sig. \\
\hline \multirow[t]{3}{*}{1} & 2 & $13.113 \% *$ & $13.113 \%$ * & $13.113 \%{ }^{*}$ \\
\hline & 3 & $14.762 \%{ }^{*}$ & $14.762 \%{ }^{*}$ & $14.762 \%{ }^{*}$ \\
\hline & 4 & $14.608 \% *$ & $14.608 \%{ }^{*}$ & $14.608 \%{ }^{*}$ \\
\hline \multirow[t]{3}{*}{2} & 1 & $-13.113 \% *$ & $-13.113 \%^{*}$ & $-13.113 \%{ }^{*}$ \\
\hline & 3 & $1.649 \% *$ & $1.649 \%^{*}$ & $1.649 \%{ }^{*}$ \\
\hline & 4 & $1.495 \% \%^{*}$ & $1.495 \%^{*}$ & $1.495 \%{ }^{*}$ \\
\hline \multirow[t]{3}{*}{3} & 1 & $-14.762 \%$ & $-14.762 \%^{*}$ & $-14.762 \%{ }^{*}$ \\
\hline & 2 & $-1.649 \% *$ & $-1.649 \%{ }^{*}$ & $-1.649 \%^{*}$ \\
\hline & 4 & $-0.153 \%$ & $-0.153 \%$ & $-0.153 \%$ \\
\hline \multirow[t]{3}{*}{4} & 1 & $-14.608 \%$ * & $-14.608 \%^{*}$ & $-14.608 \%{ }^{*}$ \\
\hline & 2 & $-1.495 \%{ }^{*}$ & $-1.495 \%^{*}$ & $-1.495 \%{ }^{*}$ \\
\hline & 3 & $0.153 \%$ & $0.153 \%$ & $0.153 \%$ \\
\hline
\end{tabular}

We also conducted a GLM univariate analysis of the variance between the two independent variables (cooperative strategies and the effect of the primaries) and the dependent variable (legislative effectiveness), but the interaction was not significant.

\subsection{Party System and Legislative Effectiveness}

As mentioned previously, one of the reasons for using Israel as a case study is the number of changes in its party system since its establishment, which we operationalized as the variable 'party system'. To assess the influence of this variable, we first ran a $\times 2$ test and found that there is a significant connection between cooperative strategies and party system $(\times 2=56.673$, sig $=0.000)$. During the one party dominant period, $68 \%$ of the MKs initiated legislation alone, while during the multi-polar fragmented period, $41.9 \%$ cooperated with MKs from other parties.

In addition, we conducted an ANOVA and a post-hoc Tukey test to determine whether different periods of the party system affected legislative effectiveness and found significant differences $(\mathrm{F}=401.319, \mathrm{Sig}=0.000)$. The one party dominant period had the highest level of legislative effectiveness. In addition, the bi-polar system period was more legislatively effective than the period of the disintegration of the big parties and the multi-polar fragmented period.

As a final analysis, we conducted a stepwise regression with legislative effectiveness as the dependent variable and the independent variables of cooperative strategies, the effect of the primaries and party system. Table 5 presents the findings. 
Table 5. Legislative effectiveness, cooperative strategies, the effect of the parties and party system.

\begin{tabular}{|c|c|c|c|c|c|c|}
\hline \multicolumn{7}{|c|}{ Coefficients $^{\text {a }}$} \\
\hline \multirow{2}{*}{\multicolumn{2}{|c|}{ Model }} & \multicolumn{2}{|c|}{ Unstandardized Coefficients } & \multirow{2}{*}{$\begin{array}{c}\text { Standardized } \\
\text { Coefficients }\end{array}$} & \multirow[b]{2}{*}{$\mathrm{t}$} & \multirow[b]{2}{*}{ Sig. } \\
\hline & & B & Std. Error & & & \\
\hline \multirow[t]{4}{*}{1} & (Constant) & 24.237 & .582 & & 41.620 & .000 \\
\hline & Cooperative strategies & .559 & .197 & .054 & 2.844 & .004 \\
\hline & Party system & -3.029 & .390 & -.313 & -7.760 & .000 \\
\hline & Primaries effect & -2.579 & .363 & -.289 & -7.116 & .000 \\
\hline
\end{tabular}

Our findings indicate that cooperating with colleagues from other parties increases the probability of passing bills. Furthermore, the early periods of the party system were the time when the likelihood of passing bills was at its height. Finally, the adoption of primaries reduced the probability of passing bills. This model explains $33.4 \%$ of the variance in legislative effectiveness.

\section{Conclusion}

MKs are rational actors, so they decide when it is best for them to cooperate or not to do so. If they choose to cooperate with their colleagues, they do so to achieve the goals they want for their voters and for themselves. In support of our first hypothesis we found that the dominant cooperative strategy is between parties. MKs do cooperate across affiliations on issues that are significant to them. Such preferences support the rational choice theory, which argues that legislators will cooperate with others whom they trust only if the potential gains are greater than the potential losses (Arrow 1963; Chaudburi et al. 2002). In addition, MKs will cooperate when they believe it will help them realize their ambition to be re-selected to run for office, re-elected or obtain a higher position (Schlesinger 1966; Treul 2009).

The data confirmed the other hypotheses as well. MKs who worked alone were more likely to pass legislation, but cooperating with MKs from other parties was more likely to result in the passage of bills than cooperating with members of the MKs' own party. These findings imply that MKs who want to pass legislation should, as rational actors, choose between acting alone or seeking inter-party cooperation. In addition, institutional changes matter. The party system and the effect of the primaries as independent variables - each one of them separately and together -affected legislative effectiveness. The one party dominant period (party system variable) and the primary-less period (the effect of the primaries variable) saw the highest level of legislative effectiveness. During the multi-polar fragmented period (party system variable) and the intermediate period (the effect of the primaries variable), legislative effectiveness reached its lowest point.

Finally, our findings indicate that cooperating with colleagues from other parties increases the probability of passing bills, the early periods of the party system saw the greatest likelihood of passing bills, and the adoption of primaries reduced the probability of passing bills.

In order to be effective in legislation, representatives must decide on their strategy for cooperating with others, understand the characteristics of the party system they work in and analyze the pros and cons of the candidate selection methods of which they are a part. All of these findings confirm the research claim that legislators as rational actors will assess the benefits and disadvantages of engaging in a particular behavior in order to be legislatively effective.

One can argue that one of the limitations of the study is the fact that it was conducted in Israel, a democracy that has only one constituency, and Israeli voters cast their ballots for political parties, not individuals. Nevertheless, as the results show, the changes in the candidate selection methods and in the party system create a special case study that allow us to analyze cooperative strategies and legislative effectiveness before, during and after these changes. However, future research should apply our model to other electoral systems to investigate whether our findings hold in them.

The study's innovation is analyzing the connection between cooperative strategies, and the effect of the primaries, party system and legislative effectiveness. Such an approach can help us understand and analyze how MKs behave as rational actors and realize their ambitions. This study is the first to look at parliamentary members in light of the strategic alliances 
they adopt based on legislative effectiveness and the effect of primaries. The study opens up a new avenue for the future study of all kinds of cooperative strategies that exist in a wide variety of legislatures and the effect that changes in candidate selection methods have on them. Such investigations can look for similarities in the cooperative strategies we found in this research or expand the explanations for them.

\section{References}

Akirav, O. (2014). "What Do Representatives Produce? Work Profiles of Representatives". Party Politics, 22(3), 1-11. https://doi.org/10.1177/1354068814549344

Arrow, K. J. (1963). Social Choice and Individual Values. Wiley, New York.

Axelrod, R. M. (1984). The Evolution of Cooperation. Basic Books, New York, US.

Barak-Erez, D. (2002). The primaries system and its constitutional effect: where is the revolution?. Theoretical Inquiries in Law, 3, 197-206.

Benvenisti, E. (2002). Party Primaries as Collective Action with Constitutional Ramifications: Israel as a Case Study. Theoretical Inquiries in Law, 3, 175-196.

Bowler, S. (2010). "Private Members' Bills in the UK Parliament: Is There an 'Electoral Connection'"? The Journal of Legislative Studies, 16(4), 476-494. https://doi.org/10.1080/13572334.2010.519457

Brams, S. J. (2014). Rational politics: Decisions, games, and strategy. Academic Press.

Campbell, J. E. (1982). "Cosponsoring legislation in the US Congress". Legislative Studies Quarterly, 7, 415-422.

Carey, J. M., \& Shugart, M. S. (1995). "Incentives to Cultivate a Personal Vote. A Rank-ordering of Electoral Formulas". Electoral Studies, 14(4):417-439. https://doi.org/10.1016/0261-3794(94)00035-2

Carter, C., Clegg, S., \& Kornberger, M. (2008), “Strategy as practice?”, Strategic Organization, 6(1), 83-99. https://doi.org/10.1177/1476127007087154

Chaudburi, A., Sopher, B., \& Strand, P. (2002). "Cooperation in Social Dilemmas, Trust and Reciprocity". Journal of Economic Psychology, 23(2), 231-249. https://doi.org/10.1016/S0167-4870(02)00065-X

Child, J., Faulkner, D., \& Tallman, S. B. (2005). Cooperative strategy. Oxford University Press.

Cox, G. W., \& McCubbins, M. D. (2005). Setting the Agenda, Cambridge: Cambridge University Press.

Cox, G. W., \& Terry, W. C. (2008). " Legislative Productivity in the 93d-105th Congresses". Legislative Studies Quarterly, 33(4), 603-618. https://doi.org/10.3162/036298008786403123

Crisp, B. F., \& Driscoll, A. (2012). "The Strategic Use of Legislative Voting Procedures". Legislative Studies Quarterly, XXXVII, 67-97. https://doi.org/10.1111/j.1939-9162.2011.00035.X

Crisp, B. F., Kanthak, K., \& Leijonhufvud, J. (2004). "The Reputations Legislators Build: With Whom Should Representatives Collaborate". American Political Science Review, 98, 703-716. https://doi.org/10.1017/S0003055404041437

Cross, W. P., Kenig, O., Pruysers, S., \& Rahat, G. (2016). Promise and Challenge of Party Primary Elections: A Comparative Perspective. McGill-Queen's Press-MQUP.

Crum, B., \& Fossum, J. E. (2009). "The Multilevel Parliamentary Field: a Framework for theorizing Representative Democracy in the EU". European Political Science Review, 1(2), 249-272. https://doi.org/10.1017/S1755773909000186

Faulkner, D. (1995). International strategic alliances: Co-operating to compete. Maidenhead: McGraw-Hill.

Fenno, R. F. Jr. (1973). Congressmen in Committees. Boston, MA: Little Brown.

Fenno, R. F. (1978). Home style: House members in their districts. Boston, MA: Little Brown.

Fowler, J. H. (2006). "Connecting the Congress: A Study of Cosponsorship Networks". Political Analysis, 14, 456-487. https://doi.org/10.1093/pan/mp1002

Garand, J. C., \& Burke, K. M. (2006). "Legislative Activity and the 1994 Republican Takeover: Exploring Changing Patterns of Sponsorship and Cosponsorship in the U.S. House.” American Politics Research, 34, 159-88. https://doi.org/10.1177/1532673X05284415

Hazan, R. Y. (2001). Reforming Parliamentary Committees: Israel in Comparative Perspective. Columbus, OH: Ohio State University Press.

Hazan, R., \& Rahat, G. (2006). The influence of candidate selection methods on legislatures and legislators: Theoretical 
propositions, methodological suggestions and empirical evidence. The Journal of Legislative Studies, 12(3-4), 366-385. https://doi.org/10.1080/13572330600875647

Hazan, R., \& Rahat, G. (2010). Democracy within parties: Candidate selection methods and their political consequences. Oxford: Oxford University Press.

Howell, W., Alder, S., Cameron, C., \& Riemann, C. (2000). "Divided Government and Legislative Productivity of Congress, 1945-94." Legislative Studies Quarterly, 25(2), 285-312.

Kessler, D., \& Krehbiel, K. (1996). "Dynamics of Cosponsorship". American Political Science Review, 90, 555-566.

Kiiver, P. (2006). The National Parliaments in the European Union: A critical View on EU Constitution Building. Den Haag: Kluwer Law International.

Kirkland , J. H., \& Gross, J. H. (2014). "Measurement and Theory in Legislative Networks: The Evolving Topology of Congressional Collaboration". Social Networks, 36, 97-109. https://doi.org/10.1016/j.socnet.2012.11.001

Koger, G. (2003). "Position Taking and Cosponsorship in the US House". Legislative Studies Quarterly., XXVII(2), 225-246. https://doi.org/10.3162/036298003X200872

Lau, Y. (2004). Coopetition in International Business. Copenhagen: Copenhagen Business School Press.

Maor, A. (2009). Private Legislation of Knesset Members. Hakibutz Hameuhad Publication. The Open University. Tel Aviv. (Hebrew).

Marangoni, F., \& Tronconi, F. (2011). "When Territory Matters: Parliamentary Profiles and Legislative Behavior in Italy (1987-2008)". The Journal of Legislative Studies, 17(4), 415-434. https://doi.org/10.1080/13572334.2011.617549

Martin. L. W., \& Vanberg, G. (2008). "Coalition Government and Political Communication". Political Research Quarterly. 61(3), 502-516. https://doi.org/10.1177/1065912907308348

Matthews, D. (1960). U.S Senators in Their World. New York: Random House.

Mayhew, D. R. (1974). Congress: The Electoral Connection. New Haven, CT: Yale University Press.

Miquel, G. P., \& Snyder, J. M. (2006). "Legislative Effectiveness and Legislative Careers". Legislative Studies Quarterly. XXXI(3), 347-381. https://doi.org/10.3162/036298006X201841

Nowak, M. (2006). "Five Rules for Evolution of Cooperation". Science., 8, 1560-1563. https://doi.org/10.1126/science.1133755

Pedersen, H. H. (2010). "How Intra-party Power Relations Affect the Coalition Behavior of Political Parties". Party Politics, 16(6), 737-754. https://doi.org/10.1177/1354068809345855

Porter, M. A. Much, P. J. Newman, E. J., \& Warmbrand, C. M. (2005). "A Network Analysis of Committees in the U.S House of Representatives". Proceedings of the National Academy of Sciences, 102(20), 7057-7062. https://doi.org/10.1073/pnas.0500191102

Powell, T. C., Lovallo, D., \& Fox, C. R. (2011). "Behavioral Strategy". Strategic Management Journal, 32(13),1369-1386. https://doi.org/10.1002/smj.968

Put, G. J., Van Hecke, S., Cunningham, C., \& Wolfs, W. (2016). The choice of spitzenkandidaten: A comparative analysis of the Europarties' selection procedures. Politics and Governance, 4(1), 9-22. https://doi.org/10.17645/pag.v4i1.469

Rahat, G., \& Hazan, R. Y. (2001). Candidate selection methods an analytical framework. Party Politics, 7(3), 297-322. https://doi.org/10.1177/1354068801007003003

Rahat, G., \& Hazan, R. Y. (2005). "Israel: The politics of an extreme electoral system". The Politics of Electoral Systems. Oxford University Press, Oxford, 333-351.

Riker, W. H. (1996). "Forward" in Schofield, N. (ed). Collective Decision-Making: Social Choice and Political Economy. Norwell MA: Kluwer Pub

Rocca, M. S., \& Gordon, S. B. (2010). The position-taking value of bill sponsorship in Congress. Political Research Quarterly, 63(2), 387-397. https://doi.org/10.1177/1065912908330347

Sandri, G., Seddone, A., \& Venturino, A. P. F. (Eds.). (2015). Party Primaries in Comparative Perspective. Ashgate Publishing, Ltd.

Schlesinger, J. A. (1966). Ambition and Politics. Political Careers in the United States. Chicago, IL: Rand McNally.

Shomer, Y. (2014). What affects candidate selection processes? A cross-national examination. Party Politics, 20(4), 533-546. https://doi.org/10.1177/1354068811436060 
Soroka, S., Penner, E., \& Blidook, K. (2009). "Constituency Influence in Parliament". Canadian Journal of Political Review, 42(3), 563-591. https://doi.org/10.1017/S0008423909990059

Strom, K. (1997). "Rules, reasons and routines: Legislative roles in parliamentary democracies". In: Muller, W.C. \& Saalfeld, T. (eds) Members of Parliament in Western Europe: Roles and Behaviour. London: Frank Cass, 155-174.

Tam-Cho, W. K., \& Fowler, J. H. (2010). "Legislative Success in a Small World: Social Network Analysis and the Dynamics of Congressional legislation". The Journal of Politics, 72(1), 124-135. https://doi.org/10.1017/S002238160999051X

Treul, S. A. (2009). "Ambition and Party Loyalty in the U.S. Senate". American Politics Research., 37(3), 449-464. https://doi.org/10.1177/1532673X08322260

Volden, C., \& Wiseman, A. E. (2014). Legislative Effectiveness in the United States Congress: The Lawmakers. Cambridge University Press.

Wawro, G. (2000). Legislative Entrepreneurship in the U.S. House of Representatives. Ann Arbor: University of Michigan Press.

Wilson, R. K., \& Young, C. D. (1997). Co-sponsorship in the U.S. Congress. Legislative Studies Quarterly, 22, 25-43

\section{Copyrights}

Copyright for this article is retained by the author(s), with first publication rights granted to the journal.

This is an open-access article distributed under the terms and conditions of the Creative Commons Attribution license (http://creativecommons.org/licenses/by/4.0/). 